\title{
MOŽNOSTI VYUŽITÍ DRUHOTNÝCH SUROVIN A RECYKLÁTŮ VE STAVEBNICTVÍ
}

\author{
APPLICATION POSSIBILITIES OF SECONDARY RAW MATERIALS AND \\ RECYCLATES IN CONSTRUCTION
}

\author{
Ing. J ana Boháčová; Ing. Stanislav Staněk
}

\begin{abstract}
ABSTRAKT CZ
Druhotné suroviny a recykláty jsou v současnosti stále více používány jako plnohodnotná náhrada standardních materiálů $\mathrm{v}$ mnoha oblastech stavebnictví, dominantní je jejich využití zejména v dopravním stavitelství. Jejich maximální využití je žádoucí, nebot' významně snižuje ekologickou zátěž a zároveň přináší investorovi nezanedbatelnou finanční úsporu. Př́ispěvek je přehledem nejčastěji používaných druhotných surovin a recyklátů a možností jejich použití ve stavebním průmyslu.
\end{abstract}

Klíčová slova: Druhotná surovina, odpad, recyklát, stavebnictví

\section{ABSTRACT}

Secondary raw materials are currently used increasingly as a full replacement of standard materials in many areas of construction, dominant use is especially in transport engineering. Maximum use is desirable because it significantly reduces the environmental burden and also brings considerable cost investor savings. The paper is a summary of the most frequently used secondary raw materials and recyclates and possibilities of their use in the construction industry.

Key words: Secondary raw material, waste, recyclate, construction

\section{1 ÚVOD}

S rozvojem lidské činnosti se výrazně rozvíjí i oblast stavitelství, technická a technologická řešení se mění v závislosti na požadavcích moderního vývoje společnosti. $\mathrm{V}$ současné legislativě je vyvíjen stále větší důraz na ochranu životního prostředí, udržitelný rozvoj a recyklovatelnost materiálů.

Druhotné suroviny a recykláty tvoří v současném stavitelství významnou část používaných materiálů a škála těchto hmot se neustále rozrůstá. Použitím druhotných surovin a recyklátů se snižuje množství odpadů, jež by bylo nutné ukládat na skládky, u některých typů surovin je výhodou možnost jejich použití ve zhoršených klimatických podmínkách. V neposlední řadě jsou pozitivem jejich použití nižší náklady.

Zároveň je však nutností dodržet při výstavbě požadavky na kvalitu konečných produktů, pro což existuje celá řada norem a technických podmínek. $Z$ tohoto hlediska je tedy při použití druhotných surovin a recyklátů bezpodmínečně nutné znát nejen jejich fyzikálně-mechanické a chemické vlastnosti v době jejich aplikace ve výstavbě, ale také se musíme zabývat dlouhodobým vývojem těchto vlastností v závislosti na působení fyzikálních, chemických a klimatických vlivů, zejména v kontextu s návrhovou životností konkrétních stavebních děl nebo jejich částí, do nichž jsou zabudovány. Přri použití alternativních materiálů je rovněž nutné zohlednit riziko nehomogenity a 
v případě stavebních demoličních odpadů také případný vliv různého původu a stáří zpracovaných materiálů. [3]

\section{RECYKLÁTY VE STAVEBNICTVÍ}

Ve stavebnictví obecně jsou jako recykláty používány především inertní minerální stavební odpady jako recyklované kamenivo do betonů a malt, povrchové úpravy pro stmelené a nestmelené aplikace a jako kamenivo pro nestmelené směsi a směsi stmelené hydraulickými pojivy pro inženýrské stavby. [2]

Z hlediska celkové produkce odpadů v rámci ČR představují stavební a demoliční odpady jeden z největších hmotnostních materiálových toků, kdy pouze tyto hmoty představují až $62 \%$ celkového produkovaného množství. Jedná se většinou o výkopové zeminy a kamenivo, jež jsou následně opět uplatňovány zejména v násypech, nezanedbatelnou částí jsou však také betonové, cihelné, asfaltové a keramické odpady a jejich směsi. V letech 2010 - 2014 bylo produkováno jen v rámci ČR cca 6400 kt betonového, 3850 kt cihelného, 71 kt keramického a 2523 kt asfaltového recyklátu. [6, 7]

Recykláty je možno z hlediska stavebnictví rozdělit zejména na betonový recyklát, asfaltový recyklát pro pozemní komunikace, recyklát z podkladních vrstev vozovek, recyklát z kameniva kolejového lože, recyklát z hornin, recyklát ze zdiva a/nebo betonových částí staveb. $[4,5]$

\subsection{Betonový recyklát}

Jedná se kamenivo vyrobené předrcením a vytříděním betonu na požadované frakce (široké nebo úzké) a výsivku (jemné podíly). Používá se do betonu a asfaltových směsí, pro hydraulicky stmelené nebo nestmelené směsi a pro zemní práce. [5]

\subsection{Asfaltový recyklát pro pozemní komunikace}

Jedná se o materiál získaný recyklací jednotlivých vrstev vozovky z asfaltových směsí, penetračních a vsypných makadamů, litého asfaltu, nátěrů a kalových zákrytů, které mohou osahovat maximálně 50 \% -ní podíl z vrstev nestmelených a stmelených hydraulickým pojivem. Obsah asfaltu musí být v minimální výši 3,5\%. Recyklát se používá do podkladních vrstev stmelených hydraulickými a/nebo asfaltovými pojivy, pro nestmelené podkladní vrstvy anebo zemní práce. [5]

\subsection{Recyklát z kameniva kolejového lože}

Jedná se o recyklát vyrobený předrcením a vytř́iěním kameniva železničního svršku, používá se při výstavbě a rekonstrucki kolejového lože železnic. [5]

\subsection{Recyklát z hornin}

Materiál definováný jako kamenivo, které bylo vyrobeno vytěžením, předrcením a vytříděním kameniva v trase výstavby komunikace nebo jiné stavby. Dělí se dle frakcí (úzké, široké, výsivka). Používá se k výstavbě a rekonstrukcím vozovek a objektů pozemních komunikací, kamenivo do betonu, do hutněných asfaltových vrstev, jako kamenivo stmelené hydraulickým pojivem, dále do stabilizovaných podkladů, nestmelených vrstev a pro zemní práce. [5]

\subsection{Recyklát ze zdiva a/nebo betonových částí staveb}

Jedná se o recyklát vyrobený předrcením a vytříděním stavební sutě, kdy kromě cihel obsahuje úlomky i dalších materiálů, zejména zatvrdlého maltového pojiva a betonu. Používá se pro podkladní vrstvy vozovek pozemních komunikací a pro zemní práce. [5] 


\subsection{Ostatní recykláty}

Mezi další, $v$ předchozích podkapitolách nezařazené recykláty lze zařadit např́klad pěnové recyklované sklo, recyklovaný pěnový polystyren, recyklované plasty, organické (dřevní) hmoty, komunální odpady aj.

U recyklátů je nutné sledovat parametry dané jednotlivými požadavky v závislosti na plánovaném použití materiálu v konstrukci.

\section{DRUHOTNÉ SUROVINY VE STAVEBNICTVÍ}

Specifickou oblastí stavitelství, v němž je velmi časté využití druhotných surovin, je dopravní stavitelství. V dopravních stavbách jsou druhotné suroviny používány zejména jako násypové materiály, k vyplňování podzemních dutin, jako kamenivo pro nestmelené směsi a pro konstrukční vrstvy a v neposlední řadě také jako součást pojiv.

V roce 2014 v ČR činila produkce druhotných surovin 18,7 mil. tun, z čehož druhotné produkty energetických procesů, tedy zejména popílky, strusky a škváry tvořily 51,6 \%, tzn. cca 10 mil. tun. [7]

V rámci severní Moravy a Slezska bylo v období let 2001 až 2011 jen na významných dopravních stavbách zužitkováno cca 4,43 mil. $\mathrm{m}^{3}$ uhelné hlušinové sypaniny, 1,73 mil. $\mathrm{m}^{3}$ vysokopecní strusky, 0,68 mil. $\mathrm{m}^{3}$ ocelářské strusky a 0,46 mil. $\mathrm{m}^{3}$ studeného odvalu. [3]

Mezi nejčastěji používané druhotné suroviny a recykláty v rámci dopravních staveb je možno zařadit zejména odpadní produkty energetického a hutnického průmyslu, uhelnou hlušinovou sypaninu a recyklované kamenivo. $\mathrm{V}$ současné době se však škála těchto materiálů neustále rozrůstá a proto se můžeme setkat také s využitím dalších, pro toto odvětví nestandardních typů materiálů. [3]

\subsection{Odpadní produkty energetického průmyslu}

Energetický průmysl vyprodukuje každoročně značné množství odpadů, a to především ve formě různých typů popílku. Na území ČR tímto ročně vzniká téměř 10 miliónů tun nového odpadu, z čehož se využívá cca jen $20 \%$, zbytek se deponován na skládkách. Elektrárenský popílek je technogenní materiál, vzniklý spalováním paliv při výrobě elektrické energie. Popílky lze rozdělit podle způsobu a technologie spalování na popílky vysokoteplotní, jež vznikají při klasickém způsobu výroby elektrické energie při teplotách 1400 - $1600{ }^{\circ} \mathrm{C}$ a popílky fluidní, které vznikají při fluidním spalování (nižší teploty a použití přísady - vápence nebo dolomitu) za atmosférického tlaku. [3, 4]

Popílky vykazují různé chemické, fyzikální i granulometrické složení, a to v závislosti na druhu spalovaného uhlí a jeho složení, způsobu spalování, způsobu těžby a přidaných aditiv. Vlivem proměnlivého chemického složení je nutné ověřovat kvalitu a složení popílků pro jejich další možné použití. Popílky jsou hojně používány do násypů pozemních komunikací, dále se uplatňují v konstrukčních vrstvách a ve formě popílkové suspenze také do krytů pro vozovky nižších tříd.

U popílků, jež jsou používány do násypů, je sledována především objemová stálost, obsah těžkých kovů a radioaktivita, dále je ověřována jejich granulometrie, objemová hmotnost, propustnost, smyková pevnost, optimální vlhkost, smyková pevnost a dále deformační moduly a kalifornský poměr únosnosti (CBR). [3]

Popílky jsou v dopravním stavitelství dále používány jako pojiva zemin, zde je nutné sledovat zejména obsah volného $\mathrm{CaO}$, pro konkrétní využití popílku je však vždy nutno provádět průkazní zkoušky. Dále jsou sledovány zejména CBR, vlhkost, bobtnání. Nejen v dopravním stavitelství se popílky používají jako příměsi do betonu a jako součást pojiv obecně. Suché elektrárenské popílky se řadí 
mezi pucolány, materiály, jež mají jen velmi slabé pojivové vlastnosti, za prrítomnosti hydroxidu vápenatého však vytvářejí hydratační produkty podobné produktům hydratace portlandského cementu. Výhodou, kromě ekologických a ekonomických aspektů, je především zlepšení zpracovatelnosti čerstvé betonové směsi, snížení množství hydratačního tepla uvolněného př̀i hydrataci cementu a snížení propustnosti vytvořeného kompozitu. V rámci požadavků na popílky, jež jsou používány jako příměs do betonů, se z chemických vlastností sleduje podíl skelné fáze, obsah volného a aktivního $\mathrm{CaO}$, obsah $\mathrm{MgO}$, chloridů, uhlíku, oxidu sírového, rozpustných fosforečnanů celkový obsah alkálií, a ztráta žíháním. Z fyzikálně-mechanických parametrů jsou ověřovány objemová stálost, počátek tuhnutí, index účinnosti, jemnost, měrná hmotnost a požadavek na množství vody. [2, 3, 4]

Pro využití jako součásti pojiva je u popílků dlouhodobě řešenou problematikou nestálost chemického složení a velmi rozdílná kvalita u různých producentů popílku.

\subsection{Odpadní produkty hutnictví}

Nejhojněji používanými odpadními produkty hutní výroby v dopravním stavitelství jsou ocelářské a vysokopecní strusky. Strusky jsou technogenním materiálem, jehož konečná struktura je závislá na rychlosti ochlazení taveniny. Patří mezi druhotné suroviny, které jsou vedlejším produktem termických a spalovacích procesů. [1,3]

Strusky se obecně dělí na vysokopecní a ocelářské, zhlediska způsobu využití v dopravním stavitelství jsou významné především struskové kamenivo a v rámci pojiv také granulovaná struska. V posledních letech je řešena v souvislosti se zvlněním D47 problematika studeného odvalu. [3]

Struskové kamenivo vzniká pomalým ochlazováním taveniny vysokopecní nebo ocelářské strusky. Při tomto pozvolném tuhnutí na vzduchu dochází ke krystalizaci strusky, následně je tato krystalická struska drcena a tř́iěna na jednotlivé frakce. Struskové kamenivo se v dopravním stavitelství používá jako kamenivo do betonu, kamenivo pro stmelené a nestmelené směsi, a jako kamenivo do asfaltových směsí. Vlastnosti struskového kameniva zásadním způsobem stanovuje použitá technologie producenta železa nebo oceli, př́ípadně jiných neželezných kovů. [1, 2, 3]

Studený odval je definován jako směs hutnických strusek, slévárenských písků a žáromateriálů (vyzdívky vysokých pecí, které vznikají při výrobě surového železa a oceli). Ve studeném odvalu je zastoupen zcela podřadně i další materiál, např́íklad dřevo, PVC aj. Použití tohoto heterogenního materiálu je specifické pouze pro ČR, v zahraničí nejsou pro stavby suroviny obdobného složení pro jejich značnou objemovou nestálost používány. [3]

Z hlediska vhodnosti použití jednotlivých typů strusek v dopravních stavbách je nutné sledování především jejich objemové stálosti. Dalšími důležitými parametry jsou granulometrie, zhutnitelnost, deformační vlastnosti a smyková pevnost. [3,4]

Granulovaná struska je připravována prudkým ochlazením taveniny vodou pod tlakem tak, aby byl zachován co nejvyšší podíl skelné fáze. Tato surovina je jako konečný produkt využívána pouze minimálně, většinou je dále zpracovávána, jejím semletím vzniká jemně mletá granulovaná vysokopecní struska, jež je pro své latentně hydraulické vlastnosti hojně využívána v cementářském průmyslu jako hlavní složka vysokopecního cementu a dále ve stavebnictví jako aktivní příměs do betonů. U vysokopecní granulované strusky patří mezi sledované parametry především železnatý a manganatý rozpad, obsah síry a objemová stálost. 


\subsection{Uhelná hlušinová sypanina}

Uhelná hlušinová sypanina je tvořena úlomky sedimentárních hornin, jež byly vytěženy při hlubinném dobývání černého uhlí, a obsahuje různé zbytkové množství tohoto uhlí. V případě, že došlo během deponování k zahoření uhelných částic, nazýváme produkt prohořelou uhelnou hlušinou. [3]

Uhelná hlušinová sypanina je v dopravním stavitelství používána při realizaci násypů, po úpravě cementem byla aplikována také jako podkladní vrstva vozovek. U hlušinové sypaniny jsou sledovány z fyzikálně-mechanických vlastností především granulometrie, zhutnitelnost, deformační vlastnosti a smykové pevnosti. Další důležité parametry jsou kromě obsahu těžkých kovů také obsah spalitelných látek a náchylnost k samovznícení. [3]

\subsection{Recyklované kamenivo}

V dopravním stavitelství je v rámci ČR nejvíce využíváno recyklované kamenivo. Tyto recykláty lze rozčlenit na recyklovanou štěrkodrt', recykláty z betonu, ze zdiva, recykláty asfaltové, recykláty z vozovek a směsné recykláty. Ve většině případů se jedná o kamenivo, jež vzniká předrcením př́ślušného odpadního materiálu. Uvedené materiály se v dopravním stavitelství uplatňují při realizaci především nestmelených vrstev, $\mathrm{v}$ případě asfaltového recyklátu je samozřejmé uplatnění $\mathrm{v}$ asfaltových vrstvách. Sledovanými parametry u recyklovaného kameniva jsou jeho geometrické vlastnosti, nasákavost, obsah jemných částic, podíl cizorodých částic, otlukovost a trvanlivostní vlastnosti. $[2,3,4,5]$

\section{ZÁVĚR}

Můžeme předpokládat, že podíl aplikací druhotných surovin a recyklátů se bude i nadále zvyšovat, a že předložený výčet používaných hmot se bude dále rožšřovat.

Nejvíce jsou dnes druhotné suroviny a recykláty využívány v silničních stavbách a to především jako násypové materiály. Některé vlastnosti popílků a strusek by však mohly být více zhodnocovány, zejména jejich využitím jako aktivní součást pojivové složky, a to jak při zlepšování vlastností zemin, tak při výrobě nových, bezcementových hmot, v nichž by se uplatnily i druhotné suroviny, jež jsou svým složením nebo granulometrií nevhodné do běžných hmot na bázi portlandského cementu.

\section{LITERATURA}

[1] M. Matoušek, "Lehké stavební hmoty“. SNTL - Nakladatelství technické literatury, Praha, 1967.

[2] J. VIDLÁŘ, Z. RŮŽIČKOVÁ, J. SRB, "Úprava druhotných surovin“. Vysoká škola báňská, Ostrava, 1985.

[3] F. Kresta, "Druhotné suroviny v dopravním stavitelství“. VŠB-TU Ostrava. Ostrava, 2012.

[4] P. SHERWOOD, "Alternative materials in road construction: a guide to the use of recycled and secondary aggregates“. 2nd ed., Thomas Telford, London, 2001.

[5] M. Škopán, "Recykláty ze stavebních a demoličních odpadů jako alternativa k přírodnímu kamenivu“, Realizace staveb, Praha, 2010.

[6] M. Škopán, "Recyklace stavebních a demoličních odpadů v prostředí oběhového hospodářství“, Recycling 2016, Brno, 2016.

[7] Tretiruka.cz, "Statistika: Produkce, využití a odstranění odpadu a produkce druhotných surovin v roce 2014“, dostupné online na http://www.tretiruka.cz/news/statistika-csuprodukce-vyuziti-a-odstraneni-odpadu-a-produkce-druhotnych-surovin-v-roce-2014/ 